Premiere Educandum: Jurnal Pendidikan Dasar dan Pembelajaran

Volume 10 (1) 1 - 8 Juni 2020

ISSN: 2088-5350 (Print) / ISSN: 2528-5173 (Online)

Doi: $10.25273 /$ pe.v10i1.5183

The article is published with Open Access at: http://e-journal.unipma.ac.id/index.php/PE

\title{
The effectiveness of the use lecture journal books in improving learning outcome of PGSD student's
}

\author{
Mohammad Archi Maulyda $\bowtie$, Universitas Mataram \\ Radiusman, Universitas Mataram \\ Muhammad Erfan, Universitas Mataram \\ Darmiany, Universitas Mataram \\ Asrin, Universitas Mataram
}

$\bowtie$ archimaulyda@unram.ac.id

\begin{abstract}
Student lecture journals are a form of development of notebooks that are commonly used by elementary, middle and high school students. Lecture journals contain a summary of lectures in one day and are made more systematically accompanied by a clear format. But the use of lecture journals at the tertiary level is still very low. Therefore, the purpose of this study is to see whether the use of lecture journals can improve student learning outcomes. The type of research chosen is quantitative to see the significance of the use of the control class and the experimental class. Data will be tested using t-independent test. T test results show that lecture journals can influence student learning outcomes. To see the enhancements used the formula test-gain / normalized gain. Based on the results of the calculation of the gain-test / normalized gain it can be seen that there is an increase in student learning outcomes for the experimental class using lecture journals in learning by $22.67 \%$. Whereas students who did not use lecture journals increased learning outcomes by only $14.6 \%$. This shows that student learning outcomes can be improved if students use lecture journals in the learning process.
\end{abstract}

Keywords: Lecture journals, Learning outcomes, Students colage, Learning

Abstrak: Jurnal perkuliahan mahasiswa merupakan bentuk perkembangan dari buku catatan yang lazimnya digunakan siswa SD, SMP dan SMA. Jurnal perkuliahan berisi rangkuman perkuliahan dalam satu hari dan dibuat dengan lebih sistematis disertai dengan format yang jelas. Namun penggunaan jurnal perkuliahan pada jenjang perguruan tinggi masih sangat rendah. Karena itu, tujuan penelitian ini adalah untuk melihat apakah penggunaan jurnal perkuliahan dapat meningkatkan hasil belajar mahasiswa. Jenis penelitian yang dipilih adalah kuantitatif untuk melihat signifikansi penggunaan kelas kontrol dan kelas eksperimen. Data akan di uji menggunakan uji t-independent test. Hasil uji t menunjukan bahwa jurnal perkuliahan dapat mempengaruhi hasil belajar mahasiswa. Untuk melihat peningkatanya digunakan rumus uji-gain/normalized gain. Berdasarkan hasil perhitungan uji-gain/normalized gain terlihat bahwa adanya peningkatan hasil belajar mahasiswa untuk kelas eksperimen yang menggunakan jurnal perkuliahan dalam pembelajaran sebesar 22,67\%. Sedangkan mahasiswa yang tidak menggunakan jurnal perkuliahan peningkatan hasil belajar hanya sebesar 14,6\%. Hal ini menunjukan bahwa hasil belajar mahasiswa dapat ditingkatkan jika mahasiswa menggunakan jurnal perkuliahan dalam proses pembelajaranya.

Kata kunci: Jurnal perkuliahan, Hasil belajar, Mahasiswa, Pembelajaran

Received 01 October 2019; Accepted 04 April 2020; Published 01 June 2020

Citation: Maulyda, M. A., Radiusman, Erfan, M., Darmiany, \& Asrin (2020). The effectiveness of the use lecture journal books in improving learning outcome of PGSD student's. Premiere Educandum : Jurnal Pendidikan Dasar dan Pembelajaran, 10(1), 1 - 8. Doi.org/10.25273/pe.v10i1.5183

Copyright (C)2020 Premiere Educandum : Jurnal Pendidikan Dasar dan Pembelajaran Published by Universitas PGRI Madiun. This work is licensed under the Creative Commons Attribution-NonCommercialShareAlike 4.0 International License. 


\section{INTRODUCTION}

Learning journals are the result of the development of notebooks. Initially notebooks are used to help students when they want to study again at home (Kartika \& Endah Mastuti, 2011). More generally, notebooks function to search for information that has been obtained before. Notebooks are also a form of effort for students to gain knowledge (Sardila, 2015). According to Hardianto (2011) students' skills in recording learning outcomes will also have a positive impact on the information / knowledge obtained by students. So the existence of notebooks is considered very important for students.

Current technological developments are actually beginning to erode the existence of notebooks little by little (Piolat, 2005). Students in the millennial era prefer to use digital data search tools to dig up information. This behavior can have positive and negative impacts. The positive is of course because digital exploration can make the insights and information obtained by students broader. But there is a negative impact that is presented, namely students become lazy to take notes and lack the fighting power in finding a knowledge or information (Aragón-mendizábal, Cándida, Delgado-casas, Inmaculada, \& Menacho-jiménez, 2016;Tsai \& Foreign, 2009).

The practice of using notebooks in schools today is also starting to cause concern. Based on the results of the study Aragón-mendizábal et al. (2016) of 38 students in the class only 8 students or only $21 \%$ of students still have a complete notebook. To clarify data related to portrait notebooks in schools researchers conducted a preliminary study of 3 schools at each level of education, namely elementary school (SD), junior high school (SMP) and senior high school (SMA) which produced the following data:

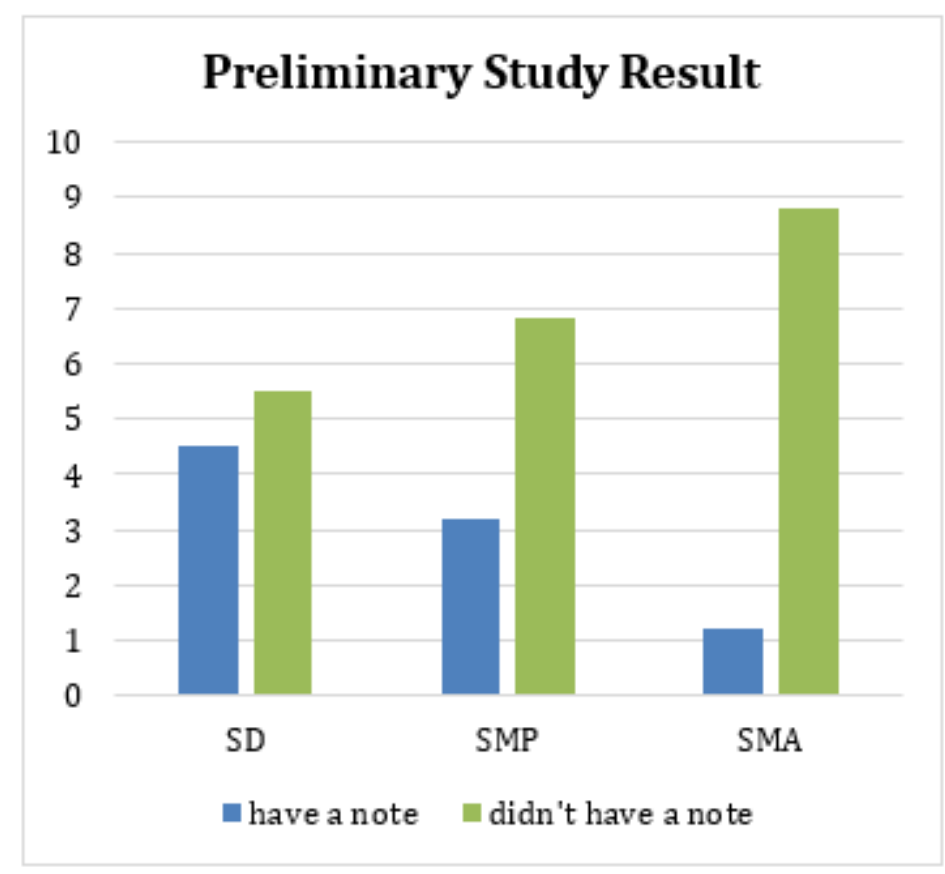

FIGURE 1. Preliminary study results

Based on the results of the data in Figure 1, it can be seen a decrease in the number of students who have notebooks at each level of education. From elementary schools, only $45 \%$ of students have notebooks, while at the junior secondary level only $32 \%$ of students have notebooks. Even at the high school level only $12 \%$ of students have notebooks. This data shows that the higher the level of student education, the fewer students have notebooks.

Even at the tertiary level, the actual notebook can also have a positive effect on student learning outcomes. According to research Morehead et al. (2019) \& Maulyda et al. 
(2019) students who can regulate themselves well will be able to improve student learning outcomes. One operational form of self-regulation is preparing notes before lectures and making notes after lectures are over. This contrasts with the results of a preliminary study conducted where the higher the level of education of students, the less likely they are to have a notebook.

Notebooks are not too popular among students. Therefore, as a development of the notebook, researchers use the term lecture journal. Different from notebooks, lecture journals have a clear and systematic format. This is done so that students can be more helpful in detecting which notes they want to find (Babatunde, 2014). Because based on the researchers' experience a lot of lecture material are interrelated with one another. For students who have entered the thesis preparation stage, it is very important to have a lecture journal to detect information obtained in previous semesters. So that systematic notes will greatly help students in the use of this lecture journal.

Seeing this fact, researchers are interested in examining the effect between the use of lecture journals on student learning outcomes. This is done to strengthen the argument related to the urgency of using lecture journals for students. Especially for the final semester students who need information that they have previously obtained can track this information through this lecture journal.

\section{METHODS}

This type of research is quantitative with a quasi-experimental approach. According to Creswell (2012) quantitative approaches can provide accurate data related to the causal relationship between two interrelated variables. This is consistent with the researcher's goal to see the effect between the use of student journals on student learning outcomes.

In this study 2 classes will be chosen as research subjects, where each class contains 30 students. Previously, researchers would conduct normality and homogeneity tests to ensure data results from both classes could be tested parametrically. Class selection is done by random sampling distribution of students in classes has been done randomly so that random class selection will not have a significant effect on the results of the study. To facilitate the mention, the first class will be given the K1 class code and the second class will be given the K2 class code. Data processing will be done by selecting class K1 as the experimental class (treated) and class $\mathrm{K} 2$ as the control class (not treated).

The implementation procedure will be carried out by giving mandatory assignments for class K1 to keep a lecture journal after each lecture. Whereas K2 class is not required to keep a lecture journal. The lecture journal is the main instrument in this study to explore its effects on student learning outcomes. The data tested to see the effect of the lecture journal is the value of the results of the pretest (assignment) and the value of the test post (UTS score) of students. To support this data, researchers will provide a questionnaire response in each class. This is done to dig deeper data related to the influence of lecture journals on learning outcomes. Following is the format of the student lecture journal.

\begin{tabular}{cccc}
\hline Hari/ & Pertemuan & Ringkasan & Ket \\
Tanggal & Ke- & & \\
\hline & & & \\
\hline
\end{tabular}

FIGURE 2. Format of Writing a Lecture Journal

\section{RESULT}

The results of the study in the form of student assignments and student midterm grades were analyzed using the SPSS software with an independent sample t-test to see the 
significance of the differences between classes K1 and K2. Furthermore, an increase in student learning outcomes will be analyzed using the gain-test / normalized gain to see how much an increase in student learning outcomes.

Before the independent sample t-test and the normalized gain test are carried out, the prerequisite test must be take place, namely normality test between the two classes and homogeneity test to check whether the two classes have homogeneous learning outcomes.

The normality test data is the result of student pretest scores. Based on the results of the normality test on the control class and experiment, the significance of the control class normality test results is 0.257 while the experimental class normality test results showed a significance of 0.457 . According to Mahoney \& Goertz (2006) the data is said to be normal when the significance is greater than 0.05 . So the control class data and the experimental class data are said to be normal.

Furthermore, researchers conducted homogeneity tests for the control class and experimental class and obtain a significance value of 0.761 . According to Mahoney \& Goertz (2006) data are said to be homogeneous when the significance is greater than 0.05 . Based on homogeneity test results, both classes have equal variance. Because the data tested for homogeneity is the result of student pretest scores, it can be assumed that the ability of students in both control and experimental classes is equal. After conducting a normality and homogeneity test, the data meet the requirements for an independent sample t-test.

The independent sample t-test was obtained after it, the t-value was equal to 11.946 while the $t$-table value is 2.001 . Because of the $t$-value is greater than $t$-table then there is a significant influence on learning outcomes between the control class and the experimental class (Creswell, 2012). Based on these data, it can be concluded that the learning outcomes of students who use lecture journals as notes are different from students who do not use lecture journals.

To see an increase in student learning outcomes, a calculation is done using the testgain / normalized gain formula to measure the increase in student learning outcomes if using a lecture journal. Here are the results of the calculation of the test gain / normalized gain (Hake, 2007):

$$
\begin{aligned}
& \text { Normalized Gain }(g)=\frac{\text { Posttest Score }- \text { Pretest Score }}{\text { Maximum Score }- \text { Pretest Score }} \\
& =\frac{79,33-64,73}{90-64,73} \\
& =\frac{14,6}{25,27} \\
& =0,57 \text { (kontrol) } \\
& \text { Normalized Gain }(g)=\frac{\text { Posttest Score }- \text { Pretest Score }}{\text { Maximum Score-Pretest Score }} \\
& =\frac{86,33-63,66}{90-63,66} \\
& =\frac{22,67}{26,34} \\
& =0,86 \text { (eksperimen) }
\end{aligned}
$$

According to (Hake, 2007) the categories of calculation results above can be interpreted as the Nominated Gain Index (g) as follows. 
TABLE 1. Interpret the Nominated Gain index ( $g$ )

\begin{tabular}{cc}
\hline Normalized Gain Score & Interpretation \\
\hline$-1.00<g<0.00$ & Decrease \\
$g=0.00$ & Stable \\
$0.00<g<0.30$ & Low \\
$0.30<g<0.70$ & Average \\
$0.70<g<1.00$ & High \\
\hline
\end{tabular}

According to the calculation results above, it can be seen that the results of the control class calculation show 0.57 results. In the category of interpretation of the Normalized Gain Index, the value of 0.57 is interpreted in the average or average category. Based on these results, it can be concluded that the increase in control class learning outcomes is not too significant. While the calculation of the test gain / normalized gain in the experimental class the value obtained is 0.86 . In the interpretation category of the Nominated Gain Index, the value of 0.86 is in the high or high category. Thus it can be concluded that student learning outcomes using lecture journals have increased significantly. Student learning outcomes not using lecture journals only increased by $14.6 \%$ while in classes using lecture journals the increase in learning outcomes increased by $22.67 \%$.

While the analysis of student response questionnaire data will be analyzed using frequency analysis on SPSS. There are three aspects that will be measured in the student response questionnaire, namely, Motivation. Following are the SPSS results from the student response questionnaire:

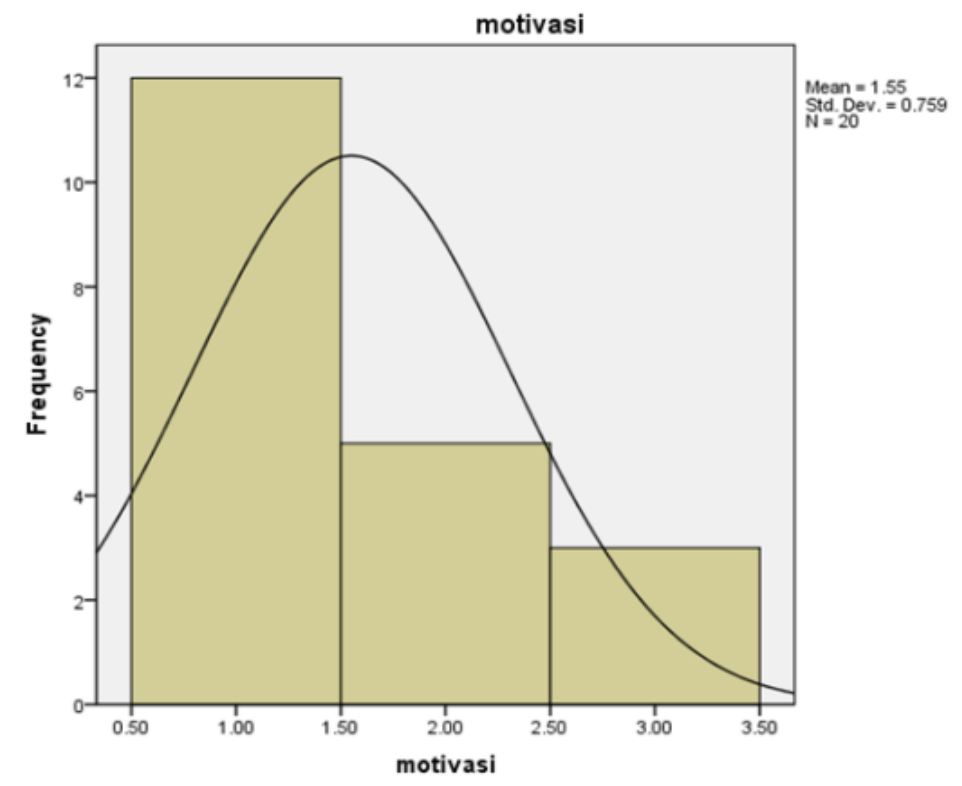

Note: strongly agree $=1.00 ;$ agree $=2.00 ;$ disagree $=3.00 ;$ Strongly disagree $=4.00$

FIGURE 3. Results of Student Motivation Frequencies

Based on the results in Figure 3, it shows that most students strongly agree with the use of lecture journal books. Students feel motivated to learn after having a lecture journal because they find it easy to access information that has been studied previously. The existence of a notebook makes students more enthusiastic in learning so that student learning outcomes also increase (Al-zoubi, 2015). This data is in accordance with the results of the SSS data calculation where students who use lecture journals have better 
learning outcomes compared to students who do not use lecture journals. This is in accordance with the results of Kiewra (2018) research which states that a good notebook will impact on student motivation. This is because students are easier when studying and reading notes about lessons that have been done before.

\section{DISCUSSION}

The results of the independent t-Test show that there is an influence between the use of lecture journals and student learning outcomes. This is consistent with the results of research conducted that notebooks are one of the effective learning materials for students. The researcher further assumes that this notebook also helps students sharpen their memory and sensitivity to a concept/material. This is supported by the opinion Nurrohmat, (2019) \& Alberini (2011) which states that by reading a book and copying it (writing it down) the brain will indirectly assume that the information entered is important information. Choi, Cho, \& Kim (2020) also states that reading and writing are two active activities that can stimulate the brain to store information that enters long-term memory (Long-term Memory). The following process of storing information according to Garderen has been modified by A. M. Maulyda (2018):

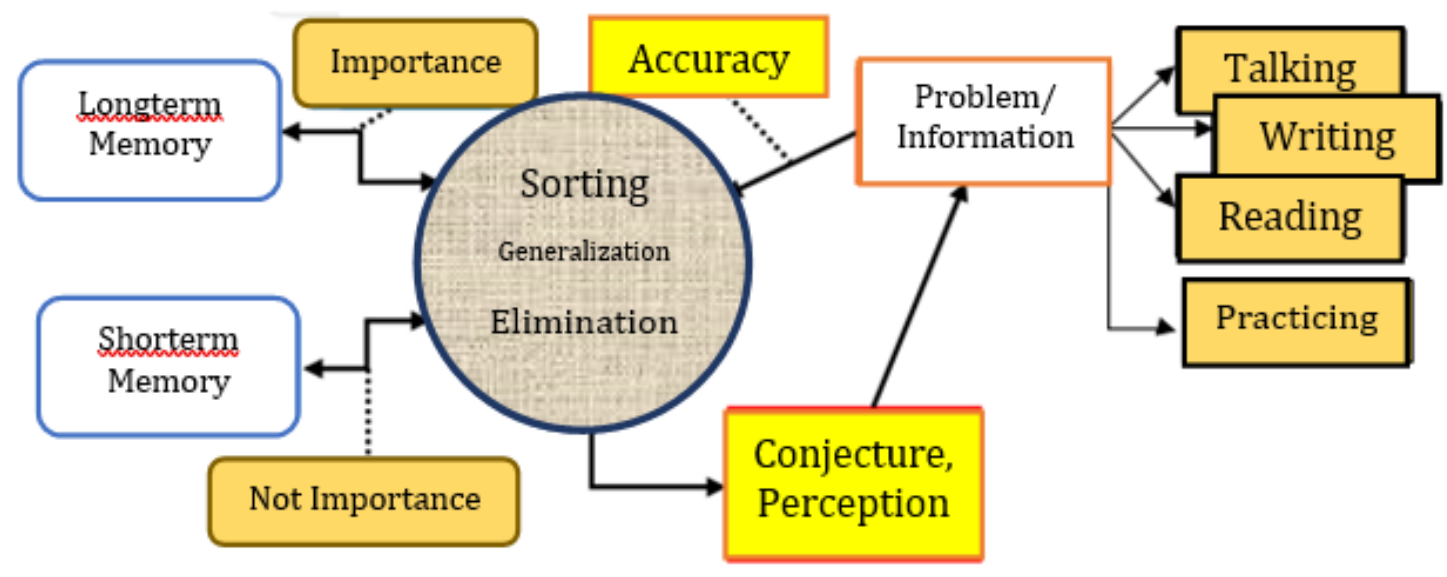

FIGURE 4. Process of Storing Information

Figure 4 shows that the importance of active activities that can be carried out to strengthen individual memories. Notebooks can make it easier for students to recall information in memory because if the information entered is already stored in long-term memory, it is easy to call the information. In addition, the influence between lecture journals and student learning outcomes is due to the tendency of students to dislike other reference reading books.

The language written in a notebook is the language of the students themselves. Making it easy for students to study again if needed. This data is strengthened by the results of the Gain test, which shows that the influence exerted by the lecture journals is very significant. Even according to the results of the interpretation of the value of $n$-Gain is in a very strong category. According to Glukhova \& Sorokina (2018) the language that is most easily understood by students is the language that is close to him. This means that the language used by peers or with family. Because this language is more easily processed by students, especially if students use their own language. Of course, if the student reads the lecture journal again, he will more easily understand the material being studied. This is what causes the influence given by the lecture journal to be very strong.

Based on the results of the student motivation questionnaire test, it can be seen that the results of the questionnaire were dominated by students who strongly agreed with the 
use of this lecture journal. Students feel the lecture journals are very useful for the student learning process before midterm and final exams. This is in accordance with the results of the study Soeprodjo, Kusuma, \& Khaerunisa (2019) where students who have lesson books tend to be easier to learn so that the learning outcomes are also good. King (2016) also supports the results of the study where at the high school level, female educator participants tend to have complete and neat notebooks. So when viewed as a whole learning outcome the value of female students tends to be better than male.

\section{CONCLUSION}

Based on the results, it can be concluded that lecture journals have a positive effect on student learning outcomes and increasing their motivation to learn. Suggestions for educators, in this case, are lecturers, namely: (1) accustom students to have lecture journals or notebooks to facilitate student learning processes; (2) routinely checking the results of student lecture journals to ensure students make lecture journals. For further research, there are a number of suggestions, namely: (1) further research should use more research subjects so that research results are more easily generalized; (2) aspects of the questionnaire student response instruments should be added, such as the effectiveness of satisfaction of students towards the use of lecture journals.

\section{REFERENCES}

1. Al-zoubi, S. M. (2015). Low Academic Achievement: Causes and Results. Theory and Practice in Language Studies, 5(11), 2262-2268.

2. Alberini, C. M. (2011). The role of reconsolidation and the dynamic process of long - term memory formation and storage. Hypothesis and Theory Article, 5(3), 1-10. https://doi.org/10.3389/fnbeh.2011.00012

3. Aragón-mendizábal, Cándida, E., Delgado-casas, Inmaculada, \& Menacho-jiménez. (2016). A Comparative Study of Handwriting and Computer Typing in Note-taking by University Students. Media Education Research Journal, 24(48), 101-107.

4. Babatunde, M. (2014). Impact Of Note Taking And Study Habit On Academic Performance Among Selected Secondary School Students In Ibadan, Oyo State, Nigeria. International Journal of Education and Research, 2(6), 437-448.

5. Choi, E., Cho, S., \& Kim, D. K. (2020). Power Demand Forecasting Using Long Short-Term Memory ( LSTM ) Deep-Learning Model for Monitoring Energy Sustainability. Sustainability, 12(1), 1-14.

6. Creswell, J. W. (2012). Educational research: Planning, conducting, and evaluating quantitative and qualitative research (4th ed.) (4th ed.). Boston, MA: Pearson.

7. Deni Hardianto. (2011). Studi Tentang Minat Baca Mahasiswa Fakultas Ilmu Pendidikan UNY. Majalah Ilmiah Pembelajaran, 7(1), 108-121.

8. Glukhova, I., \& Sorokina, O. (2018). Student-Centered Education in Context of SecondLanguage Learning. SHS Web of Conferences 50, 01057, 50. Russian: Web of Science.

9. Hake, R. . (2007). sign-Based Research in Physics Education Research: A Review," in A.E. Kelly, R.A. Lesh, \& J.Y. Baek, eds. (in press), Handbook of Design Research Methods in Mathematics, Science, and Technology Education (1st ed.). New York: SAGE Publication.

10. Kartika, L., \& Endah Mastuti. (2011). Motivasi Membaca Literatur Berbahasa Inggris pada Mahasiswa Psikologi Universitas Airlangga Surabaya. INSAN, 13(03), 185-192.

11. Kiewra, K. A. (2018). Note This : How to Improve Student Note Taking. IDEA, 73(7), 1-18.

12. King, A. H. (2016). Navigating Collaboration: A Multimodal Analysis of Turn-Taking in Coteaching. TESOL \& Applied Linguistics, 16(2), 56-62.

13. Mahoney, J., \& Goertz, G. (2006). A Tale of Two Cultures: Contrasting Quantitative and Qualitative Research (1st ed.). https://doi.org/10.1093/pan/mpj017

14. Maulyda, A. M. (2018). Representasi Matematis Anak yang Berbakat di Bidang Musik dalam Menyelesaikan Masalah Matematis. Universitas Negeri Malang.

15. Maulyda, M. A., Hidayati, V. R., Rosyidah, A. N. K., \& Nurmawanti, I. (2019). Problem-solving ability of primary school teachers based on Polya's method in Mataram City. PYTHAGORAS: Jurnal Pendidikan Matematika, 14(2), 139-149. 
16. Morehead, K., Dunlosky, J., Rawson, K. A., Blasiman, R., Hollis, R. B., Morehead, K., \& Blasiman, R. (2019). Note-taking habits of 21st Century college students: implications for student learning, memory, and achievemen. Memory, $0(0), 13$. https://doi.org/10.1080/09658211.2019.1569694

17. Nurrohmat, M. A., \& Sn, A. (2019). Sentiment Analysis of Novel Review Using Long Short-Term Memory Method. Indonesian Journal of Computing and Cybernetics Systems, 13(3), 209-218.

18. Piolat, A. (2005). Note Taking and Learning : A Summary of Research. The WAC Journal, 16(2), 101-113.

19. Sardila, V. (2015). Strategi Pengembangan Linguistik Terapan Melalui Kemampuan Menulis Biografi Dan Autobiografi : Sebuah Upaya Membangun. Jurnal Pemikiran Islam, 40(2), 110117.

20. Soeprodjo, Kusuma, E., \& Khaerunisa, E. N. (2019). Efektivitas Model Pembelajaran Kooperatif Tipe Berpikir-Berpasangan-Berempat Berbantuan Catatan Terbimbing Terhadap Hasil Belajar Kimia SMA Negeri 1 Unggaran. Jurnal Inovasi Pendidikan Kimia, 5(2), 759-765.

21. Tsai, T., \& Foreign, A. (2009). EFL College Freshman Note-Taking Training for Reading Comprehension. The Journal of Human Resource and Adult Learning, 5(2), 12-18.

\section{PROFILE}

Mohammad Archi Maulyda adalah dosen program studi pendidikan guru sekolah dasar, fakultas keguruan dan ilmu pendidikan, Universitas Mataram. Ia juga merupakan editor di Penerbitan IRDH pada divisi penerbitan buku. Selain itu ia aktif dalam projek penelitian pada bidang kemampuan dasar matematika dalam NCTM.

Radiusman adalah dosen program studi pendidikan guru sekolah dasar, fakultas keguruan dan ilmu pendidikan, Universitas Mataram. Selain itu ia aktif dalam projek penelitian pada bidang etnomathematika.

Muhammad Erfan adalah dosen program studi pendidikan guru sekolah dasar, fakultas keguruan dan ilmu pendidikan, Universitas Mataram. Ia juga merupakan editor dari Jurnal Pendidikan IPA Universitas SAMAWA. Selain itu ia aktif dalam projek penelitian pada bidang pendidikan IPA dan Pendidikan Fisika.

Darmiany adalah dosen program studi pendidikan guru sekolah dasar, fakultas keguruan dan ilmu pendidikan, Universitas Mataram. Ia juga merupakan reviewer internal untuk proposal penelitian dan pengabdian kepada masyarakat di Universitas Mataram. Selain itu ia aktif dalam projek penelitian pada bidang konseling anak dan psikologi anak.

Asrin adalah dosen program studi pendidikan guru sekolah dasar, fakultas keguruan dan ilmu pendidikan, Universitas Mataram. Ia juga merupakan editor dari jurnal Pendidikan Dasar (PenDas) Prodi PGSD Universitas Mataram. Selain itu ia aktif dalam projek penelitian pada bidang pendidikan karakter. 